перевірка ефективності науково-методичних засад фахової підготовки тьюторів у системі вищої освіти України; методи математичної статистики, застосовані для опрацювання отриманих даних і вивчення кількісних залежностей між аналізованими явищами і процесами. Результати формувального етапу експерименту засвідчили ефективність організаційно-педагогічних умов готовності науково-педагогічних працівників до тьюторської діяльності. Одержані кількісні дані наприкінці формувального етапу в порівняльному аспекті з кількісними показниками констатувального етапу дослідження дали змогу зафіксувати позитивну динаміку: в експериментальних групах слухачів узагальнений показник рівня готовності до названого виду діяльності зріс із низького до високого; у контрольних групах - iз низького до середнього. Отже, кількісний та якісний аналіз результатів експериментальної роботи підтвердили доцільність впровадження запропонованої системи заходів професійної підготовки тьюторів.

Ключові слова: тьютор, тьюторська діяльність, педагогічні інновації, підготовка, компетентність.

Submitted on April, 6, 2017

UDC: 373.1

DOI: https://doi.org/10.24195/2414-4665-2017-4-27

Olena Vasylenko,

PhD (Candidate of Pedagogical Sciences), associate professor, Department of Psychology and Pedagogy,

Alla Sheremet,

PhD (Candidate of Pedagogical Sciences), senior teacher, Department of Social Work and Social Pedagogy, Khmelnytsky National University, 11, Instytutska Str., Khmelnytskyi, Ukraine

\title{
PECULIARITIES OF CAREER SELF-DETERMINATION OF MODERN HIGH SCHOOL STUDENTS
}

The issue of career self-determination of modern high school students is highly crucial at present when labour market is constantly developing thus increasing requirements for modern specialists training. Some young people do not have clear perspectives on life and feel insecure, unconfident. Other high school students choose careers which are of no demand at enterprises and that is why they work in the specialty they have no qualification for. The paper aims to study motives and factors influencing the process of career self-determination of modern high school students and specify effective methods of cultivating students' conscious attitude towards making a future career choice. The school students were asked to do a survey using the questionnaire designed by authors. Besides, the respondents' personal ability to make a career choice was determined using techniques "What do I like?" (by L. Jovaiša) and "Career Map" by Ye. Klimov. The received results enable us to find out positive and negative factors which affect the process of career self-determination of modern high school students and to study what motivates students when they make their career choices. Basing on the research results it can be concluded that the most effective methods to cultivate career self-determination in high school students are trainings in particular the one called "Life map: to make one's own career choice".

Keywords: career, career self-determination, high school students, motives and factors of career selfdetermination, methods of cultivating one's career self-determination.

\section{Introduction}

The issue of career self-determination of high school students has always been interesting for leading scientists and practitioners as this issue covers the decisive moment in the life of every person. This issue is highly crucial for early adolescence period as at this age young people's central mental new formation is focused on their future which determines their general perspective on life, appreciating themselves as part of a society, their awareness of being adults and at last outlining their purposes in life.

The obstacles which modern young people challenge on their way to self-determination are mostly associated with current problems such as the period of social and economic changes in our country when neither parents nor school are able to help them make their career choice. That is why a great number of school leavers choose prestigious jobs of a lawyer, an economist, a journalist, a manager, etc. Very few want to choose a career in the sphere of material production, social service, etc. Another problem is that an unsuccessful career choice that is without taking into account personal abilities and possibilities can result in a young person's losing perspectives on life and in some cases can lead to social maladjustment [2].

K. Abulhanova-Slavska, Ye. Holovah, O. Kadenko. Ye. Klimov, R. Nikov, N. Priazhnikov, V. Safin studied the issue of a career choice. V. Bodrov, A. Holomshtok, 
Ye. Klimov, I. Nazimov, K. Platonov, N. Pobirchenko, V. Syniavskyi, V. Sliastionin, M. Smulson, B. Fedoryshyn and others considered the issue of personal motivation for making a career choice and a person's qualification for a workplace.

Career self-determination has been the issue for discussion not only in sociology, pedagogy, labour psychology and developmental psychology but in acmeology as well. It studies common factors of mental development of an individual in the period of his/her development (acme) which is also characterized by professional growth and taking steps to one's expertise (B. Ananiev, O. Anisimov, A. Bodaliov, V. Hladkova, S. Honcharenko, A. Derkach, N. Kuzmina, I. Pidlasyi, S. Sysoieva, A. Sytnykov).

We should claim that modern researchers associate the study of common factors of inner mental basis of career self-determination with one's awareness of this choice within one's life and personality selfdetermination, experiencing oneself, finding one's role in this world, analysing one's own personal potential and analyzing whether one's own potential can meet career requirements (V. Zhuravliov, I. Zaziun, I. Kon, T. Kudriavtseva, A. Kuharchuk, V. Safin, V. Shynkaruk and others).

Scholars mostly focus on the peculiarities of life and personal self-determination of youth in their scientific researches. Here, the issue of figuring out the factors which influence the process of career self-determination of modern high school students are vaguely studied as well as the issue of studying what motivates students when they make their career choices.

Thus, the aim of this paper is to study the motives and factors which influence the process of career selfdetermination of modern high school students and to find out effective methods of cultivating students' conscious attitude towards their future career choices.

\section{Methods}

The experiment involved 83 students among who there were 40 eleventh-graders and 43 tenth-graders of Khmelnytskyi specialized comprehensive school № 8 (SCS № 8). In our research we used the questionnaire designed by us. The respondents were surveyed to figure out motives and factors which influence their career choice. We also used methodology "What do I like?" (by L. Jovaiša) and Ye. Klimov's methodology "Career map" to study the respondents' personal ability to make career choices.

\section{Discussion}

Representatives of different science domains take attempts to succeed in defining the phenomenon of career self-determination though this issue still remains unsolved. Thus, in Ukrainian science there are many developments in theory of career self-determination which outline modern approaches how to define this term. It is appropriate here to note instructive studies by Ye. Klimov, Ye. Holovah. They emphasize personal aspects of career self-determination [7, p. 122-127].
Ye. Klimov bases his opinion on activity approach when defining self-determination: "Career selfdetermination is a person's activity which takes a new meaning depending on what stage of the development he/she is as a labour participant" [3]. We share the opinion of Priazhnikov who defines self-determination in the following way: "Career self-determination is one's independent and conscious searching for the sense of work which is being done and the whole life activity in a specific cultural and historical (social and economic) situation" [6]. The main purpose of self-determination is gradual building of inner readiness for conscious and independent creating, correcting and realizing the perspectives of one's own professional development, readiness to find personal sense in a specific professional activity.

When choosing a career, school leavers mostly take into account the level of education, location of an educational institution, possibilities of employment after graduating from the institution and the salary. That is why one of the ways to make a career choice easier is to develop and improve career guidance. The informative and methodological basis of career guidance is profound knowledge about the nature and conditions of occupation, the right vision of the requirements to psychophysiological and personal qualities of a person, psycho-diagnostic evaluation of a person's individual and mental peculiarities and their comparison with various activities [1, c. 7]. The absence of such knowledge can negatively affect a career choice or its changing.

A lot of factors affect the process of selfdetermination. In our opinion, though, the most significant one is a pedagogical (psychological) factor which is the cause, the driving force of any pedagogical (psychological) phenomenon. Its components are as follows: inclinations (interests, motives); abilities, health (inner possibilities and limits); self-esteem; parents' and other relatives' opinions; peers' opinions; teachers' opinions, specialists' opinions; personal professional plan (the knowledge about what and how a person wants to achieve).

Though there are some negative aspects among the positive ones in the self-determination of high school students, for example, the fact that school students rely on the opinions of random people, their career choice is based on the first impression about this job, they choose this job because their friends choose it, or only because it is prestigious, young people do not take into account their own abilities or they choose their career to hurt someone, they ignore their health limits.

Not only do these factors influence the career choice of young people. Their motives affect the choice in a great degree as well. There is a wide range of motives which can be grouped into social, moral, aesthetic, cognitive, creative, material, prestigious, utilitarian and a group of motives related to a specific specialty [8].

We conducted an experimental work with 83 tenth and eleventh graders of Khmelnytskyi SCS № 8 to study the peculiarities of career self-determination of modern 
students. We used such methods and methodologies as our authors' questionnaire, L. Jovaiša's methodology of studying students' personal abilities to make a career choice "What do I like?" and Ye. Klimov' methodology "Career map".

To start an experimental study, we gave a minilecture on the topic "Motives and factors of an effective career self-determination of high school students". We used it as one of verbal teaching methods which is an oral presentation of academic material during a short period of time (15 min.) and is characterized by a large amount and complexity of logic constructs, images, evidence and summaries. The goal of this mini-lecture was to develop an appropriate and conscious view about a future career in high school students.

We considered the following main questions:

1. The importance of a proper agreement between students' ambitions, possibilities and needs of a society in the jobs they choose.

2. Consequences of motivated and unmotivated career choice.

3. The consideration of motives and factors which influence self-determination of high school students.

The survey results show that most eleventh graders (70\%) already know what occupation they want to choose, though $30 \%$ students do not know their career preferences yet. The students ranked the jobs in the following way: a lawyer (20\%) and a banker (15\%) were given first rank. Then there goes a politician, a businessman, a doctor, a judge, a journalist (10\% each). And nobody chose a profession of a teacher, a fire fighter or an engineer. When the students were asked "Do you think it is possible to enter a higher educational establishment relying only on your own abilities without a parents' financial support?" $75 \%$ of them answered positively though $25 \%$ of them replied that they did not think so. $50 \%$ of the students attend sport clubs, interest clubs, electives, private classes in order to be enrolled a specialty they like. Many students $(55 \%)$ believe that it will help them make a career choice. $80 \%$ of the students consider the Open Day at universities to be a very useful contributing to the making of career choice.

The results of the conducted survey among 43 tenth graders of SCS № 8 have shown that most students make their choice in favour of well-advertised professions of a programmer, a tax officer, a lawyer, a banker while the professions of a teacher, a firefighter and an engineer were not chosen at all. The negative aspect is that most of the respondents do not think it is efficient to attend sport clubs, interest clubs, elective, private lessons which can enhance their chance to be enrolled in the specialty they dream about. Moreover, tenth graders are reluctant to attend Open Day, open classes, classes in classrooms and laboratories in higher educational establishments. And the determining factors when choosing a career are knowledge and abilities necessary for this profession, the possibility of successful employment in the chosen specialty. Unfortunately, negative factors which make the choice the most complicated are parents' payment failure and the lack of knowledge about a desired job. In addition, the job role and people's opinion about it are also significant factors.

Another methodology which we have used in our research is "What do I like?" (L. Jovaiša). The students answered from 1 to 150 question on their answer sheets. These questions expressed students' problems and personal qualities clearly. Questions "What do I like?", "Would you like...?", "Do you like ...?" (to learn to draw, to read about the forest, to spend time in the forest, to learn to cook, to learn to draw) were supposed to reveal the abilities and the professions which the respondents preferred.

The eleventh graders are well aware of new technologies and that is why they choose those activities which imply the use of computer technologies or career promotion. The most popular professions with high school students have turned to be an economist, a sportsman, a military man, a sailor and an aviator, an electrical engineer, an actor, a man of law.

The results show that tenth graders prefer such career activities as sports, military service, advocacy, economy and acting. While the jobs in metal and wood processing domains, consumer goods industry, forestry, geology are not popular at all. It may be explained that these jobs are not considered to be prestigious and well-paid and school teachers are reluctant to unveil this myth and to explain the advantages of these jobs.

We used Ye. Klimov's technique "Career Map" in this study to identify such a complicated phenomenon as career orientation. We aimed to figure out high students' inclinations to a particular type of a profession such as "person-person", "person-sign system", "person-nature", "person-character", "person-machinery".

$35 \%$ eleven graders chose a profession of "personmachinery" and $25 \%$ of them turned to be inclined to a profession of "person-person" type. The same number of students prefers professions of the type «personcharacter» (15\%) and "person-sign system" (15\%). And only $10 \%$ students chose a profession of the "personnature" type (Fig. 1). 


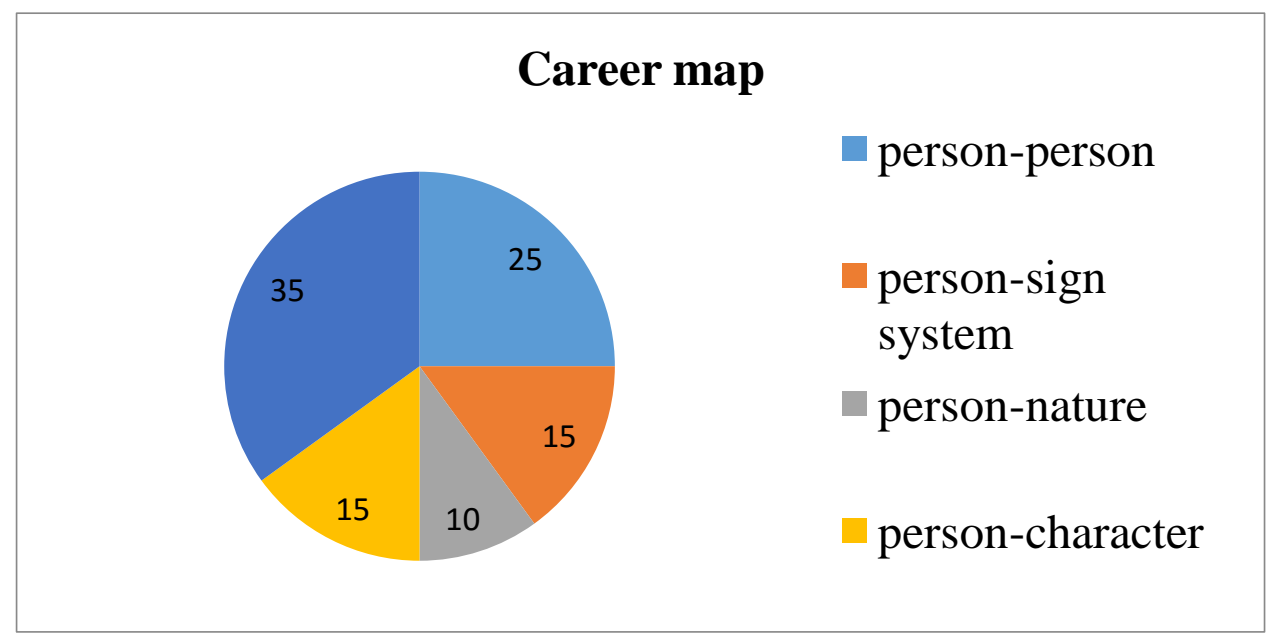

Fig. 1. The results of Ye. Klimov's technique «Career Map» (eleventh graders (\%))

So, most eleventh graders want to choose the professions which are related to such activities as creating, mounting, exploiting, fixing (mostly boys chose these professions) and upbringing, teaching, managing, medicine (mostly girls preferred these professions).
After tenth graders of SCS № 8 were surveyed using Ye. Klimov's "Career Map" the results show that tenth graders preferred professions of the type "person-person" (41,9\% students) and "person-machinery" (23,2\% students). Students were not interested in professions of the "person-nature" and "person-character" types (Fig. 2).

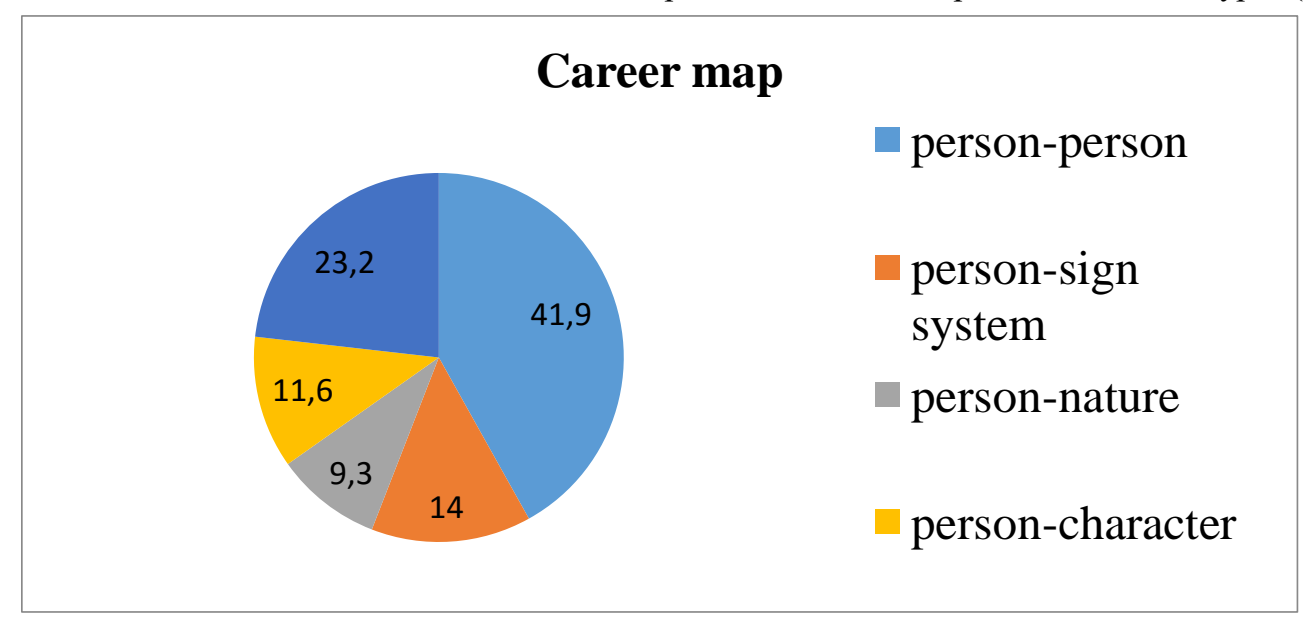

Fig. 2. The results of Ye. Klimov's technique “Career Map” (tenth graders (\%))

Having analyzed the results we can say that it is necessary to take the following factors into account when developing high school students' career selfdetermination:

- first, some qualities which are important for future career are vague in adolescence as there are no conditions for their exposing;

- the second factor is the lack of self-comprehension, mood swing, wrong self-evaluation;

- the third factor is the lack of life experience (the lack of knowledge about professions and labour market, possible mistakes when making a career choice).

The development and implementation of efficient forms and methods of career guidance by specialists of secondary educational establishments can reduce the negative impact of these factors on high school students' choice. We believe that the most effective method here is to conduct trainings which have the following tasks:
to enhance students' knowledge about professions

to provide their informative and psychological support when preparing students to take admission tests or interviews when applying for a job;

to enable students to get aware of evident obstacles on the way to professional success;

- $\quad$ to teach students to use arguments to support their own point of view when talking with their parents, friends, teachers, etc.;

- $\quad$ strengthening planning perspectives on life and career.

To perform these tasks we offer to use M. Kornilova's training "Life Map: making one's own career choice" 
modified by us [5]. This training consists of three sessions lasting for three hours and a half each. We worked out a draft structure of a training program "Life Map: to make one's own career choice" for high school students (see Table 1).

Table 1.

The structure of a training program "Life Map: to make one's own career choice” for high school students

\begin{tabular}{|c|c|c|c|}
\hline № & Activity & Time & Materials \\
\hline \multicolumn{4}{|c|}{ Session 1} \\
\hline 1.1. & $\begin{array}{l}\text { Greeting, introduction. The topic and the goal of } \\
\text { the training. The presentation of the formula of a } \\
\text { career choice "Want - Can - Must". }\end{array}$ & $20 \mathrm{~min}$ & - \\
\hline 1.2. & Activity "Diary" & $40 \mathrm{~min}$ & A notebook, a pen \\
\hline 1.3 & Activity "Bus stop" & $25 \min$ & $\begin{array}{l}\text { Three Whatman drawing paper } \\
\text { sheets }\end{array}$ \\
\hline 1.4. & $\begin{array}{l}\text { Students discuss and set the rules of working in a } \\
\text { group }\end{array}$ & $15 \mathrm{~min}$ & $\begin{array}{l}\text { A Whatman paper sheet, a } \\
\text { marker pen }\end{array}$ \\
\hline 1.5. & Activity "The competition of motives" & $10 \mathrm{~min}$ & Paper, a pencil \\
\hline 1.6. & Activity "Lottery game" & $15 \min$ & Cards, pens \\
\hline 1.7. & Activity "My career desires" & $15 \min$ & A list of uncompleted sentences \\
\hline 1.8. & Activity "Guess a job" & $10 \mathrm{~min}$ & Board, chalk \\
\hline 1.9. & $\begin{array}{l}\text { Activity "There once lived a grey goat at the gran- } \\
\text { ny's" }\end{array}$ & $15 \mathrm{~min}$ & Paper, a pencil \\
\hline 1.10 . & Activity "The test of final content" & $20 \mathrm{~min}$ & $\begin{array}{l}\text { Five sheets of paper per one } \\
\text { participant, pencils, felt-pens }\end{array}$ \\
\hline 1.11 & $\begin{array}{l}\text { Closure: "I was ..., because..." (to complete a } \\
\text { sentence). Feedback. }\end{array}$ & $15 \mathrm{~min}$ & 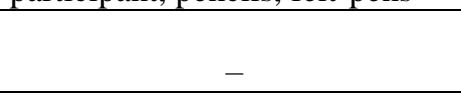 \\
\hline \multicolumn{4}{|c|}{ Session 2} \\
\hline 2.1. & $\begin{array}{l}\text { Greeting: "If I were a director I would shoot a film } \\
\text { about..." (to complete a sentence) }\end{array}$ & $10 \mathrm{~min}$ & - \\
\hline 2.2. & The technique to turn a dream into a goal & $60 \mathrm{~min}$ & - \\
\hline 2.3. & Activity "A walk to the mountains" & $30 \mathrm{~min}$ & $\begin{array}{l}\text { Sheets of paper, pencils, felt } \\
\text { pens, listed feelings }\end{array}$ \\
\hline 2.4. & Activity "One's own image of the world" & $30 \mathrm{~min}$ & $\begin{array}{l}\text { Sheets of paper, pencils, felt } \\
\text { pens }\end{array}$ \\
\hline 2.5 & Activity "What is success in life" & $40 \mathrm{~min}$ & Tables \\
\hline 2.6. & $\begin{array}{l}\text { Homework: to write an essay "The purpose of my } \\
\text { life" }\end{array}$ & $10 \mathrm{~min}$ & A questionnaire for parents \\
\hline 2.7. & Closure. Feedback & $15 \min$ & A sheet of paper, a pen \\
\hline \multicolumn{4}{|c|}{ Session 3} \\
\hline 3.1. & Greeting "Compliment circle" & $10 \mathrm{~min}$ & - \\
\hline 3.2 . & Information announcement "The world of jobs" & $15 \mathrm{~min}$ & - \\
\hline 3.3 . & Activity "The chain of jobs" & $10 \mathrm{~min}$ & - \\
\hline 3.4 . & Activity "Checklists" & $20 \mathrm{in}$ & $\begin{array}{l}\text { Lists of questions for each par- } \\
\text { ticipant }\end{array}$ \\
\hline 3.5 . & Decision algorithm & $40 \mathrm{~min}$ & $\begin{array}{l}\text { Whatman paper sheets, old } \\
\text { newspaper, magazines, scissors, } \\
\text { glue, felt pens }\end{array}$ \\
\hline 3.6. & Activity «Fairy tale "Want-Can-Must» continuation" & $40 \mathrm{~min}$ & Paper, pencils, felt pens \\
\hline 3.7. & Activity "Mistakes ranking" & $20 \mathrm{~min}$ & $\begin{array}{l}\text { List «mistakes when making a } \\
\text { career choice» }\end{array}$ \\
\hline 3.8. & Activity "Adviser" & $20 \min$ & A set of paper cards \\
\hline 3.9. & Reading homework essays “The purpose of my life" & $20 \mathrm{~min}$ & - \\
\hline 3.10 & $\begin{array}{l}\text { Collection of evaluating judgments. Training wrap- } \\
\text { ping up }\end{array}$ & $15 \mathrm{~min}$ & - \\
\hline
\end{tabular}


The training is expected to result in:

- enhancing students' interest to make their career choice individually on the basis of their personal features, inclinations and abilities to meet the demands of modern labour market;

- cultivating skills to be able to make a conscious and responsible career choice;

- developing students' comprehension of "Mecharacter" and "Me-my future career image";

- nurturing a conscious attitude of students to analyze and solve the problem of making their career choices individually: self-evaluation of their personal abilities and how these abilities meet the demands of jobs at labour market;

- making a reasonable choice of relevant areas of expertise necessary for future career (self-education, selftraining), a technique and working out an algorithm of self-determination.

It should be mentioned that career guidance will be successful when school teachers involve parents as well since data received during the survey show that parents often influence students' career choices. That is why parents should take an active part in their children's outlining life and career goals.

\section{REFERENCES}

1. Hladkova, V. M. (2007). Profooriientatsiina robota: navchalnyi posibnyk [Proforientational work: textbook]. Lviv: Novyi Svit-2000 [in Ukrainian].

2. Kadenko, O. M., Vasylenko, O. M. (2010). Mekhanizmy formuvannia profesiinoho samovyznachennia vypusknykiv zahalnoosvitnikh shkil ta shliakhy yikh modeliuvannia [Mechanisms of forming professional self-determination of school leavers and ways of their modelling]. Zb. nauk. pr. Uman. derzh. ped. un-tu imeni Pavla Tychyny - Collection of scientific works of Pavlo tychyna State Pedagogical University, 4, 101-107. Uman: UDPU imeni Pavla Tychyny [in Ukrainian].

3. Klymov, E. A. (1996). Psykholohiia profesionala [Psychology of a professional]. Moscow: Akademyia [in Ukrainian].

4. Oriientyry dlia vyboru profesii [Orientations for the occupational choice]. Retrieved from: http://www.profosvita.org.ua/uk/guide/articles/8.html. [in Ukrainian].

\section{ЛІТЕРАТУРА}

1. Гладкова В.М. Профорієнтація: [навчальний посібник] / В. М. Гладкова. - Львів: Новий Світ-2000, 2007. - $160 \mathrm{c}$.

2.Каденко О. М Механізми формування професійного самовизначення випускників загальноосвітніх шкіл та шляхи їх моделювання / О. А. Каденко, О. М. Василенко // Зб. наук. пр. Уман. держ. пед. ун-ту імені Павла Тичини. - Умань : УДПУ імені Павла Тичини, 2010. -Ч. 4. - С. 101-107.

\section{Conclusions}

Thus, the results of this study enable us to find positive and negative aspects which affect the process of career selfdetermination of modern high school students and to study what motivates them when they make their career choices. We have found out that a positive aspect is that most of school leavers believe it is possible to use their own abilities to enter a higher educational establishment without their parents' financial support. A negative factor which makes the choice difficult to make is the lack of knowledge about their future job and their parents' payment failure. Another negative aspect is that high school students most focus on prestigious and well-advertised jobs believing that they are well-paid and interesting.

After having analyzed the results we came to the conclusion that the most effective methods of forming career self-determination of high school students are trainings, in particular M. Kornilova's training "Life map: to make one's own career choice" which we modified for tenth and eleventh graders and presented the draft structure.

We think that the results obtained should be taken into consideration when working out a career guidance program for high school students and this is the issue of further study in this field.

5. Proforiientatsiinyi treninh «Karta zhyttia: samostiinyi vybir maibutnoi profesii» (dlia uchniv 9-kh klasiv) [Proforientational training "Life map: independent occupational choice"]. Retrieved from: te.zavantag.com>docs/717/index-29406-1.html [in Ukrainian].

6. Priazhnykov, N. S. (1996). Professionalnoe $i$ lichnostnoe samoopredelenie [Professional and personal self-determination]. Moscow-Voronezh [in Russian].

7. Rudiuk, O. (2006). Psykholohichni osoblyvosti profesiinoho samovyznachennia bezrobitnoi molodi $\mathrm{v}$ protsesi profpereoriientatsii [Psychological peculiarities of professional self-determination of unemployed youth in the process of professional reorientation]. Sotsialna psykholohiia - Social psychology, 5, 122-127 [in Ukrainian].

8. Skyba, M. Ye., Kokhanko, O. M. (2007). Teoriia $i$ praktyka profesiino-oriientatsiinoi roboty $z$ moloddiu: navchalnyi posibnyk [Theory and practice of proforientational work with youth: textbook]. Khmelnytskyi: KhNU [in Ukrainian].

3.Климов Е. А. Психологія професіонала / Е. А. Климов. - М.: Академия, 1996. -400 с.

4.Орієнтири для вибору професії [Електронний pecypc]. $\quad$ - $\quad$ Режим доступу: http://www.profosvita.org.ua/uk/guide/articles/8.html. Загол. з екрану. - Мова укр.

5.Профорієнтаційний тренінг «Карта життя: самостійний вибір майбутньої професії» (для учнів 9-х класів) [Електронний ресурс]. - Режим доступу: 
te.zavantag.com>docs/717/index-29406-1.html - Загол. 3 екрану. - Мова укр.

6.Пряжников Н. С. Профессиональное и личностное самоопределение / Н. С. Пряжников. Москва-Воронеж, 1996. - 67 с.

7.Рудюк О. Психологічні особливості професійного самовизначення безробітної молоді в про- цесі профпереорієнтації / О. Рудюк // Соціальна психологія. - 2006. - № 5. - С. 122-127.

8. Скиба М. С. Теорія і практика професійноорієнтаційної роботи з молоддю: [навчальний посібник] / М. С. Скиба, О. М. Коханко. - Хмельницький: XНУ, 2007. - 322c.

Олена Миколаӥвна Василенко, кандидат педагогічних наук, доцент кафедри психології та педагогіки, Хмельницький національний університет, вул. Інститутська 11, м. Хмельницький, Україна, Алла Михайлівна Шеремет, кандидат педагогічних наук, стариий викладач кафедри сочіальної роботи та сочіальної педагогіки, Хмельницький національний університет, вул. Інститутська 11, м. Хмельницький, Украӥна,

\section{ОСОБЛИВОСТІ ПРОФЕСІЙНОГО САМОВИЗНАЧЕННЯ СУЧАСНИХ СТАРШОКЛАСНИКІВ}

У статті розглядається проблема професійного самовизначення сучасних старшокласників. Особливої актуальності ця проблема набуває у ранньому юнацькому віці, оскільки центральним новоутворенням психічного розвитку юнаків є орієнтація на майбутнє, яка визначає загальну життєву перспективу: зрозуміти себе в якості повноцінного члена суспільства, зайняти внутрішню позицію дорослого та визначити своє місце в суспільному житті. Сутністю професійного самовизначення особистості є самостійне та усвідомлене знаходження сенсу роботи, що виконується, $\mathrm{i}$ всієї життєдіяльності в конкретній культурно-історичній (соціально-економічній) ситуації. Метою статті є дослідження мотивів і чинників, які впливають на процес професійного самовизначення сучасних старшокласників та визначення дієвих методів формування усвідомленого ставлення учнів до вибору майбутньої професії. У дослідженні були використані такі методи та методики, як: анкетування учнів за розробленою анкетою, що дозволило визначити мотиви і чинники, які впливають на вибір професії випускниками шкіл; методику дослідження особистісної здатності учнів до вибору професії: «Що мені подобається?» (Л. Йовайши), методику «Карта світу професій» за С. Клімовим. У дослідно-експериментальній роботі прийняли участь 83 учні 10-х та 11-х класів СЗОШ № 8 м. Хмельницького. Отримані результати проведеного дослідження показали, що сучасні старшокласники здебільшого орієнтуються на престижні та добре розрекламовані в суспільстві професії, вважаючи їх високо оплачуваними $\mathrm{i}$ цікавими. Позитивним чинником професійного самовизначення старшокласників $є$ те, що більшість 3 них вважають можливим вступити до вищого навчального закладу за рахунок власних здібностей без матеріальної підтримки батьків. А негативним чинником, який ускладнює вибір професії сучасними старшокласниками, $\epsilon$ недостатній рівень їхніх знань про майбутню професію та платіжна неспроможність їхніх батьків. Знизити вплив негативних чинників, які впливають на процес професійного самовизначення сучасних старшокласників, можна тільки шляхом розробки та впровадження дієвих форм і методів формування професійного самовизначення учнів. На думку авторів, найефективнішим методом є тренінгові заняття, зокрема тренінг «Карта життя: самостійний вибір майбутньої професії» автора М. Корнілової, який було адаптовано для учнів 10-11 класів та розроблено його орієнтовну структуру. Отримані результати проведеного дослідження варто враховувати при розробці програм профорієнтаційної роботи зі старшокласниками, що і $є$ перспективами подальших розвідок у цьому напрямку.

Ключові слова: професія, професійне самовизначення, старшокласники, мотиви і чинники професійного самовизначення, методи формування професійного самовизначення.

Submitted on April, 7, 2017

Reviewed by Doctor of Pedagogy, prof. O. Homoniuk 